\title{
KOMBINASI ALKOHOL DAN ASAP CAIR SEBAGAI ALTERNATIF PENGAWET SPESIMEN CACING TANAH (Pheretima sp.)
}

\author{
Ani Sri Rahayoe ${ }^{1}$ \\ ${ }^{1}$ Laboratorium Sistematik Hewan, Fakultas Biologi, Universitas Gadjah Mada, \\ Yogyakarta, anisri.r@ugm.ac.id
}

Submisi: 26 Oktober 2018 ; Penerimaan: 30 Juni 2019

\begin{abstract}
ABSTRAK
Pengawetan spesimen merupakan upaya untuk mempertahankan keadaan mahluk hidup sehingga dapat dipergunakan untuk kepentingan pendidikan dan penelitian. Pengawetan spesimen sangat terkait dengan pelaksanaan praktikum sistematika hewan. Asap cair grade-2 tempurung kelapa telah diketahui berpotensi sebagai pengawet yang aman. Untuk itu perlu dilakukan penelitian untuk mengevaluasi pengaruh kombinasi alkohol dan asap cair sebagai pengawet spesimen cacing tanah (Pheretima sp.) dan kisaran kombinasi yang baik.

Penelitian merupakan penelitian eksperimen dilaksanakan pada bulan Oktober sampai dengan Desember 2018. Cacing tanah diberi 11 perlakuan kombinasi alkohol 70\% dan asap cair grade-2. Perbandingan alkohol:asap cair dibuat (10:0), (9:1), (8:2), (7:3), (6:4), (5:5), (4:6), (3:7), (2:8), (1:9), dan (0:10) dengan 3 kali ulangan. Cacing diambil di daerah Pringgolayan, Banguntapan, Bantul, Yogyakarta. Pengamatan dilakukan 2 minggu sekali, terhadap keadaan specimen (meliputi: warna, keutuhan, dan kekenyalannya) dan larutan (meliputi: warna dan kejernihannya).

Hasil penelitian hingga Minggu IV menunjukkan seluruh perlakuan mampu mengawetkan spesimen, keutuhan, dan kekenyalan tetap terjaga. Semakin tinggi kadar asap cair menyebabkan warna yang semakin gelap. Hal ini disebabkan oleh Hb darah spesimen mengikat karbon dalam larutan. Kombinasi perlakuan II (alkohol:asap cair=9:1) hingga perlakuan $V$ (kombinasi alkohol:asap cair=6:4) memberikan hasil kenampakan spesimen yang baik. Kombinasi tersebut tampak lebih baik dari pada perlakuan I (alkohol $70 \%$ murni) dan perlakuan XI (asap cair grade-2). Hasil awetan spesimen perlakuan I, warna merah tampak memudar, tubuh lebih lunak, dan beberapa bagian menyusut.
\end{abstract}

Kata kunci: asap cair; cacing tanah; alkhohol; pengawetan .

\section{PENDAHULUAN}

Pengawetan

spesimen

merupakan upaya yang dilakukan untuk mempertahankan keadaan mahluk hidup sebagaimana keadaan di alam dalam jangka waktu yang lama. Bagi kepentingan praktikum sistematika dan keanekaragaman maka pengawetan harus mampu mempertahankan kondisi alami dan struktur morfologi (hanya sedikit perubahan) serta terbebas dari bakteri dan jamur yang dapat mengakibatkan pembusukan. Ketersedian spesimen awetan sangat diperlukan untuk efisiensi waktu pelaksanaan praktikum sistematika dan keanekaragaman karena banyaknya jumlah maupun ragam jenis yang harus dipersiapkan laboran dalam setiap acara praktikum.

Salah satu metode pengawetan spesimen adalah dengan cara pengawetan basah. Pengawetan basah dilakukan dengan mengawetkan objek biologi dalam suatu larutan kimia. Larutan kimia yang biasa digunakan adalah alkohol $70 \%$ dan formalin $4 \%$ yang dapat digunakan secara tunggal ataupun kombinasi keduanya. Namun hasil awetan dari keduanya dalam jangka waktu lama dapat menjadi rapuh dan warna spesimen menjadi pudar. Larutan tersebut juga memiliki kandungan zat berbahaya sehingga 
penggunaan jangka panjang akan berisiko bagi kesehatan.

Penelitian Rahayoe (2016) menggunakan asap cair tempurung kelapa grade-2 sebagai alternatif pengawet spesimen ikan nila (Orechromis niloticus) menunjukkan hasil bahwa asap cair mampu mengawetkan sebanding dengan awetan menggunakan alkohol $70 \%$, warna ikan dapat dipertahankan namun tekstur ikan kurang kenyal. Kombinasi alkohol 70\%:asap cair grade-2 (1:1) menunjukkan hasil awetan yang lebih baik berdasarkan warna dan tekstur yang dihasilkan dibandingkan dengan penggunaan alkohol atau asap cair secara terpisah (pengawet tunggal). Kombinasi keduanya menunjukkan adanya interaksi kedua larutan tersebut.

Asap cair tempurung kelapa atau bagian lain seperti sabut merupakan hasil dari pirolisis dan destilasi atau pendinginan sehingga diperoleh cairan berwarna coklat pekat. Asap cair grade2 merupakan hasil penyaringan asap cair dengan zeolite sehingga menghasilkan cairan lebih jernih dengan warna kuning kecoklatan. Asap cair grade-2 dapat dipergunakan sebagai pengawet bahan makanan pengganti formalin (Yulstiani, 2008). Penggunaan asap cair sebagai pengawet selain harga relatif lebih murah juga lebih aman. Menurut Hendry, dkk. (2008) asap cair masuk dalam kategori zat tidak tosik sehingga penggunaan dalam jangka yang panjang tidak berisiko terhadap kesehatan pengguna.

Berdasarkan paparan di atas maka kombinasi alkohol dan asap cair sebagai pengawet spesimen perlu diteliti lebih lanjut dengan variasi kombinasi. Penelitian ini menggunakan spesimen cacing tanah (Pheretima sp.) sebagai salah satu spesimen yang digunakan dalam praktikum sistematika hewan dan keanekaragaman hewan. Cacing tanah memiliki tubuh yang lunak, memiliki segmen-segmen di tubuhnya, dan berpigmen warna merah. Keadaan tersebut diharapkan memberi kemudahan pada saat pengamatan terhadap perubahan yang terjadi selama penelitian. Tujuan penelitian ini adalah: pertama, untuk mengetahui pengaruh kombinasi dari alkohol $70 \%$ dan asap cair grade-2 terhadap kualitas spesimen awetan cacing tanah dan kedua, untuk menentukan kisaran kombinasi alkohol $70 \%$ dan asap cair grade-2 yang baik untuk pengawetan cacing tanah. Dari penelitian ini diharapkan akan diperoleh alternatif pengganti bahan pengawet spesimen yang baik dan aman bagi kesehatan.

\section{METODE PENELITIAN}

Bahan yang digunakan dalam penelitian meliputi: spesimen cacing tanah (Pheretima sp.) berdasarkan identifikasi dan determinasi Laboratorium Sistematika Hewan, Fakultas Biologi UGM. Spesimen diperoleh dari ladang di Dusun Pringgolayan, Desa-Kecamatan Banguntapan, Kabupaten Bantul, Yogyakarta. Kemikalia yang digunakan berupa: asap cair grade-2 (produksi Laboratorium Rekayasa Proses, Fakultas Teknologi Pertanian UGM), dan alkohol teknis $70 \%$.

Penelitian merupakan penelitian eksperimental, spesimen cacing tanah dimasukkan ke dalam $20 \mathrm{ml}$ larutan kombinasi asap cair grade-2 dan alkohol $70 \%$ dalam botol falcon. Kombinasi larutan terdiri dari 11 perlakuan dengan perbandingan alkohol:asap cair: I. 10:0 alkohol 70\% ; II. 9:1; III. 8:2; IV. 7:3; V. 6:4; VI. 5:5; VII. 4:6; VIII. 3:7; IX. 2:8; X. 1:9; dan XI. 0:10 (asap cair grade 2). Masing-masing perlakuan diberi label terdiri dari: kode perlakuan (angka romawi), ulangan (angka arab) dan bahan/perbandingan kombinasi 
alkohol:asap cair. Untuk pengukuran yang presisi digunakan gelas ukur 10 $\mathrm{ml}$. Masing-masing perlakuan diulang 3 (tiga) kali. Pada minggu ke IV (sebagaimana dalam praktik di laboratorium Sistematik Hewan, Fakultas Biologi, UGM) larutan kombinasi diganti dengan yang baru.

Dilakukan pengamatan pada minggu II, IV, VI, dan VIII terhadap warna spesimen, keutuhan spesimen (segmentasi tubuh), kekenyalan, warna larutan, dan kejernihan larutan. Terhadap kekenyalan spesimen selain dilakukan secara kualitatif dengan menekan-nekan tubuh spesimen juga diuji secara kuantitatif menggunakan alat Texture Analyzer. Pengujian dilakukan di laboratorium Rekayasa Proses Pengolahan, Fakultas Teknologi Pertanian, UGM . Penelitian dilakukan pada bulan Oktober - Desember 2018.

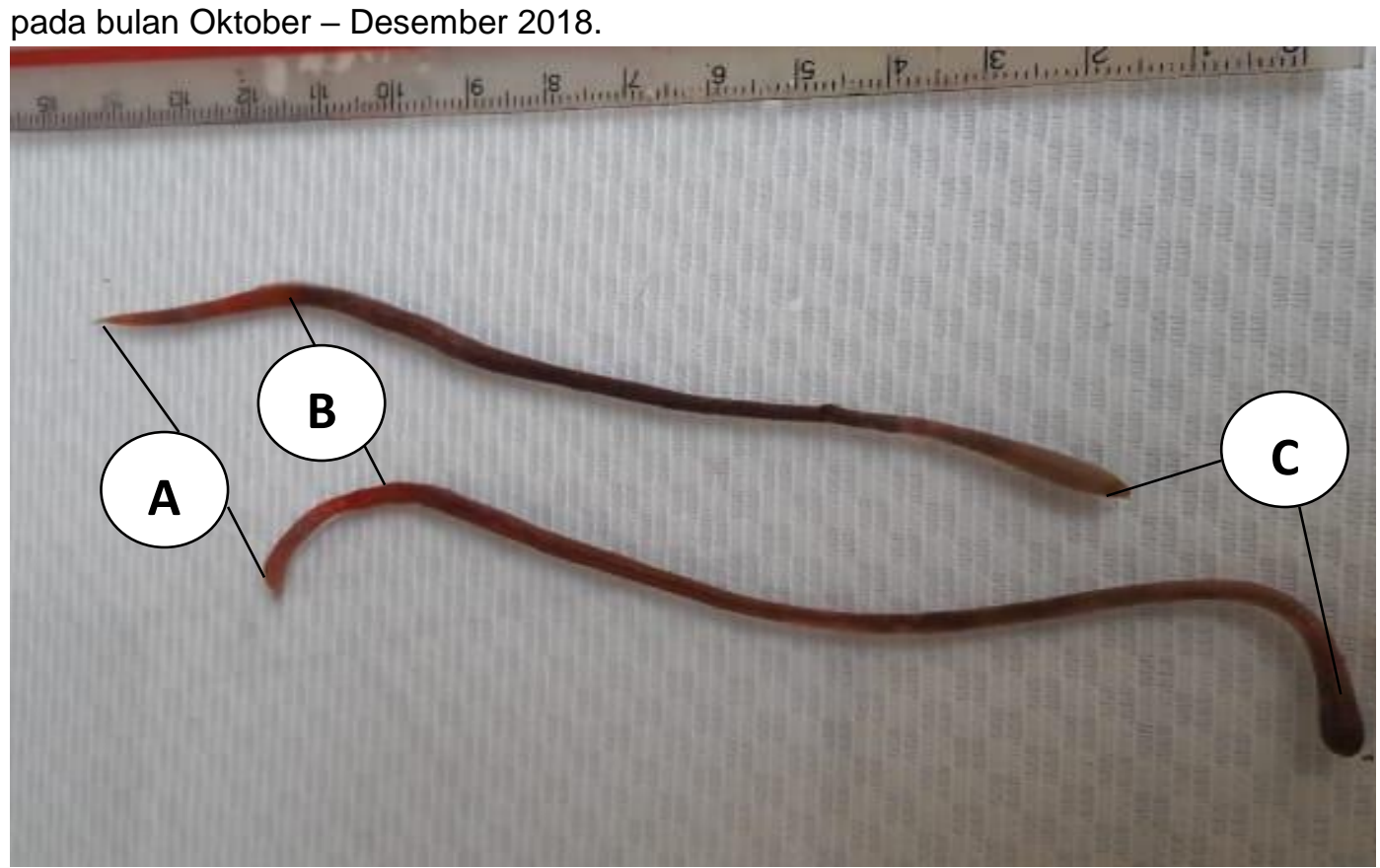

Gambar 1. Cacing tanah yang diambil dari lokasi. A. Bagian anterior B. Posterior dan C. Clitellum. Bentuk tubuh gilig bersegmen jelas.

Cacing merupakan anggota hewan invertebrata yang bertubuh lunak dengan segmen sederhana yang jelas. Struktur tubuhnya gilig memanjang tersusun oleh segmen-segmen otot

\section{HASIL DAN PEMBAHASAN}

Cacing tanah (Pheretima sp.) diambil dari ladang di dusun Pringgolayan berukuran sekitar 10-15 $\mathrm{cm}$ sebagaimana Gambar 1. tampak berwarna kemerah-merahan dan terlihat bagian clitellum yang menebal berwarna merah muda. Penelitian dilakukan untuk mengamati kemampuan kombinasi dari alkohol $70 \%$ dan asap cair grade-2 sebagai pengawet jenis cacing tersebut. Masing-masing perlakuan diulang 3 kali. Pada saat cacing dimasukkan ke dalam larutan pengawet tubuh cacing memendek namun kenampakan clitellum dan segmen tubuh cacing tetap bisa diamati. 
otot maka cacing dikelompokkan dalam Phylum Annelida (annulus $=$ cincin dan oidos=bentuk) (Brusca and Brusca, 1990; Edward and Robert,1994). Cacing tanah dipilih dalam penelitian ini selain memang merupakan spesimen yang digunakan dalam praktikum Sistematika dan Keanekaragaman Hewan (invertebrata), dikarenakan tubuhnya yang lunak, berdiameter kurang dari 0,5 $\mathrm{cm}$ sehingga cepat difiksasi/diawetkan. Di samping itu, pigmen tubuhnya yang kemerahan dapat digunakan sebagai indikasi kualitas proses pengawetan.

Pada awal perlakuan larutan yang digunakan dalam perlakuan secara kasat mata dapat dilihat larutan pelakuan I (alkohol 70\%) dan II (alkohol:asap cair=9:1) tampak transparan dan jernih, perlakuan II (alkohol 70\%:asap cair $=4: 6$ ) sampai dengan VI (alkohol 70\%:asap cair $=5: 5$ ) terlihat coklat kekuningan jernih, dan pada perlakuan VII-XI larutan menunjukkan warna yang semakin kecoklatan karena pengaruh warna asap cair tempurung kelapa grade-2. Pada pengamatan minggu II maka beberapa larutan tampak adanya perubahan warna dan terbentuk endapan sebagai hasil reaksi kimia yang terjadi (Tabel 1.).

Pada pengamatan minggu II, secara umum tekstur permukaan tubuh (segmen) nampak tidak ada pengelupasan, keseluruhan spesimen tubuh dalam keadaan kenyal, warna masih nampak kemerahan kecuali pada perlakuan I (alkohol 70\%) warna spesimen mulai memudar. Ditemukan adanya endapan pada 10 perlakuan, yaitu pada perlakuan: III-3, IV-1, IV-3, V3, VI-1, VI-2, VI-3, VIII-1, VIII-3, dan IX-3 (Gambar 2.). Adanya endapan adalah akibat dari lendir atau jaringan luar cacing yang lunak terlepas dari tubuh. Endapan semakin banyak karena adanya jaringan yang terbuka atau luka yang yang ditimbulkan saat pengambilan sampel. Semakin besar luka terbuka akan timbul endapan yang lebih banyak. Bercampurnya isi jaringan tubuh bagian yang dalam termasuk darah dengan larutan dapat menimbulkan warna larutan yang lebih gelap sebagaimana pada perlakuan VI1, VI-2, dan VIII-1.
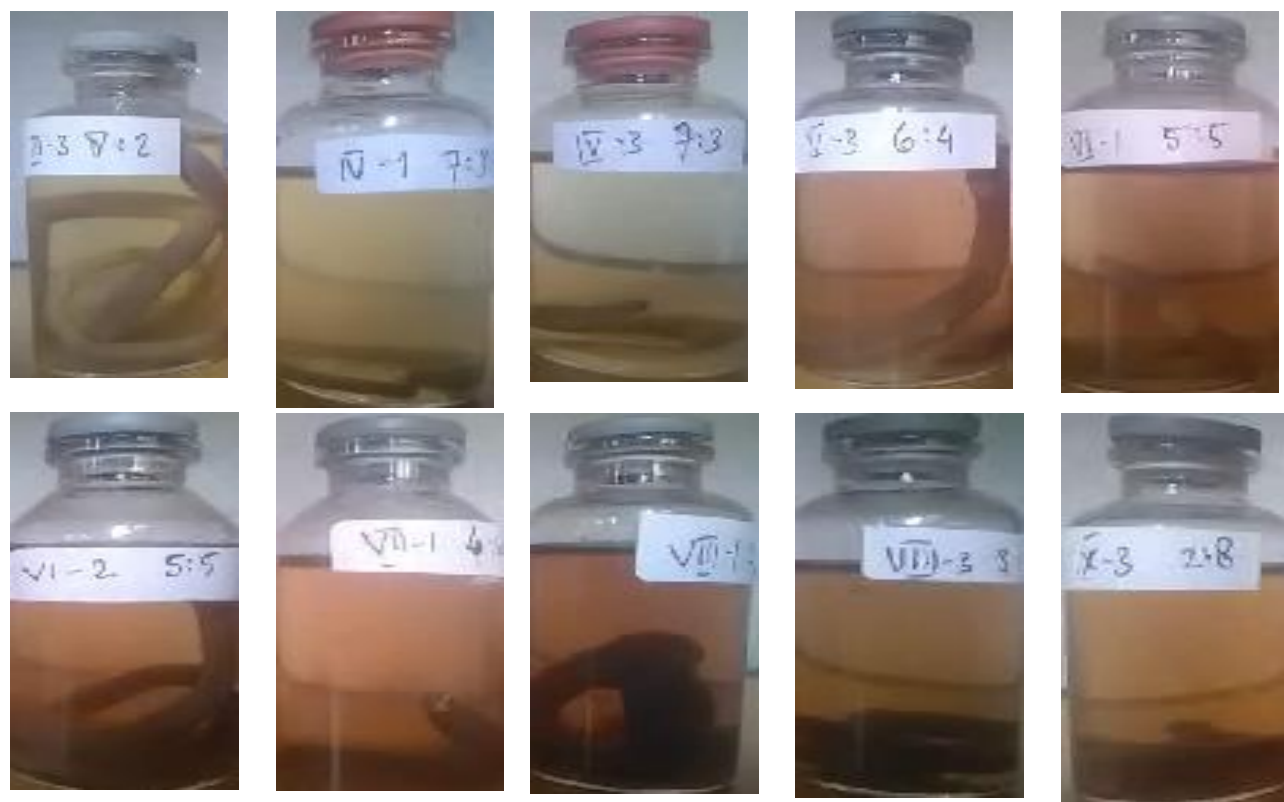

Gambar 2.Hasil pengamatan pada Minggu II muncul endapan cukup banyak pada perlakuan V-3, VI-1, VI-2, VII-1, dan VIII-1 
Tabel 1. Pengamatan Spesimen dan Larutan pada Minggu II (21 Oktober 2018)

\begin{tabular}{|c|c|c|c|c|c|c|}
\hline \multirow[t]{2}{*}{ No } & \multirow{2}{*}{$\begin{array}{c}\text { Perlakuan/ } \\
\text { ulangan }\end{array}$} & \multicolumn{3}{|c|}{ Spesimen } & \multicolumn{2}{|c|}{ Larutan } \\
\hline & & Warna & Segmen & Tekstur & Warna & Kejernihan \\
\hline \multirow[t]{3}{*}{1} & I.1 Alkohol & Memudar & Utuh & Kenyal & Transparan & Jernih \\
\hline & I.2 Alkohol & Memudar & Utuh & Kenyal & Transparan & Jernih \\
\hline & I.3 Alkohol & Memudar & Utuh & Kenyal & Transparan & Jernih \\
\hline \multirow[t]{3}{*}{2} & II.1 $9: 1$ & Kemerahan alami & Utuh & Kenyal & Transparan & Jernih \\
\hline & II.2 9:1 & Kemerahan alami & Utuh & Kenyal & Transparan & Jernih \\
\hline & II.3 9:1 & Kemerahan alami & Utuh & Kenyal & Transparan & Jernih \\
\hline \multirow[t]{3}{*}{3} & III.1 $8: 2$ & Kemerahan alami & Utuh & Kenyal & Kekuningan & Jernih \\
\hline & III.2 8:2 & Kemerahan alami & Utuh & Kenyal & Kekuningan & Jernih \\
\hline & III.3 8:2 & Kemerahan alami & Utuh & Kenyal & Kekuningan & $\begin{array}{l}\text { Jernih, sedikit } \\
\text { endapan }\end{array}$ \\
\hline \multirow[t]{3}{*}{4} & IV.1 $7: 3$ & Kemerahan alami & Utuh & Kenyal & Kecoklatan & Jernih \\
\hline & IV.2 7:3 & Kemerahan alami & Utuh & Kenyal & Kecoklatan & Jernih \\
\hline & IV.3 7:3 & Kemerahan alami & Utuh & Kenyal & Kecoklatan & $\begin{array}{l}\text { Jernih, sedikit } \\
\text { endapan }\end{array}$ \\
\hline \multirow[t]{3}{*}{5} & V.1 $6: 4$ & Kemerahan alami & Utuh & Kenyal & Kecoklatan & Jernih \\
\hline & V.2 $6: 4$ & Kemerahan alami & Utuh & Kenyal & Kecoklatan & Jernih \\
\hline & V.3 $6: 4$ & Kemerahan alami & Utuh & Kenyal & Kecoklatan & $\begin{array}{l}\text { Jernih, banyak } \\
\text { endapan }\end{array}$ \\
\hline \multirow[t]{3}{*}{6} & VI.1 $5: 5$ & Kemerahan alami & $\begin{array}{l}\text { Utuh } \\
\text { Ada luka }\end{array}$ & Kenyal & Agak Coklat & $\begin{array}{l}\text { Jernih, banyak } \\
\text { endapan }\end{array}$ \\
\hline & VI.2 5:5 & Kemerahan alami & $\begin{array}{l}\text { Utuh } \\
\text { Ada luka }\end{array}$ & Kenyal & Agak Coklat & $\begin{array}{l}\text { Jernih, banyak } \\
\text { endapan }\end{array}$ \\
\hline & VI.3 $5: 5$ & Kemerahan alami & Utuh & Kenyal & Kecoklatan & Jernih \\
\hline \multirow[t]{3}{*}{7} & VII. $14: 6$ & Kemerahan alami & $\begin{array}{l}\text { Utuh } \\
\text { Ada luka }\end{array}$ & Kenyal & Kecoklatan & $\begin{array}{l}\text { Jernih, banyak } \\
\text { endapan }\end{array}$ \\
\hline & VII.2 4:6 & Kemerahan alami & Utuh & Kenyal & Kecoklatan & Jernih \\
\hline & VII.3 4:6 & Kemerahan alami & Utuh & Kenyal & Kecoklatan & Jernih \\
\hline \multirow[t]{3}{*}{8} & VIII.1 3:7 & Kemerahan alami & $\begin{array}{l}\text { Utuh } \\
\text { Ada luka }\end{array}$ & Kenyal & Agak coklat & $\begin{array}{l}\text { Jernih, banyak } \\
\text { Endapan }\end{array}$ \\
\hline & VIII.2 3:7 & Kemerahan alami & Utuh & Kenyal & Kecoklatan & Jernih \\
\hline & VIII.3 3:7 & Kemerahan alami & Utuh & Kenyal & Kecoklatan & $\begin{array}{l}\text { Jernih, sedikit } \\
\text { Endapan }\end{array}$ \\
\hline \multirow[t]{3}{*}{9} & IX.1 2:8 & Kemerahan alami & Utuh & Kenyal & Agak coklat & Jernih \\
\hline & IX.2 2:8 & Lebih gelap & Utuh & Kenyal & Agak coklat & Jernih \\
\hline & IX.3 2:8 & Lebih gelap & Utuh & Kenyal & Agak coklat & $\begin{array}{l}\text { Jernih } \\
\text { Endapan }\end{array}$ \\
\hline \multirow[t]{3}{*}{10} & X.1 $1: 9$ & Lebih gelap & Utuh & Kenyal & Coklat & Jernih \\
\hline & X.2 $1: 9$ & Lebih gelap & Utuh & Kenyal & Coklat & Jernih \\
\hline & X.3 1:9 & Lebih gelap & Utuh & Kenyal & Coklat & Jernih \\
\hline \multirow[t]{3}{*}{11} & $\mathrm{XI} .1 \mathrm{AC}$ & Lebih gelap & Utuh & Kenyal & Coklat & Jernih \\
\hline & $\mathrm{XI} .2 \mathrm{AC}$ & Lebih gelap & Utuh & Kenyal & Coklat & Jernih \\
\hline & XI.3 AC & Lebih gelap & Utuh & Kenyal & Coklat & Jernih \\
\hline
\end{tabular}

Hasil dari proses pengawetan specimen minggu IV dapat dilihat pada Tabel 2. Secara umum tekstur permukaan terlihat baik, demikian juga kekenyalannya, hanya saja warna tubuh beberapa spesimen tampak menghitam. Asap cair tempurung kelapa grade-2 yang digunakan terlihat adanya warna kecoklatan, warna tersebut ditimbulkan oleh sisa-sisa karbon. Sisa-sisa karbon 
ini tampaknya menyebabkan spesimen yang diperlakukan dengan konsentrasi asap cair semakin pekat menunjukkan warna spesimen yang semakin gelap (coklat hingga menghitam). Sisa-sisa karbon diduga terikat kuat dengan pigmen darah atau haemoglobin $(\mathrm{Hb})$ darah Cacing tanah. $\mathrm{Hb}$ darah dalam sistem peredaran darah berperan mengikat gas-gas oksigen maupun karbon dioksida. Dalam larutan asap cair yang terlarut karbon akan berperan dalam mengikat karbon yang ada sehingga tubuh cacing menjadi terakumulasi karbon sehingga tampak warna coklat hingga hitam (Gambar 3.).
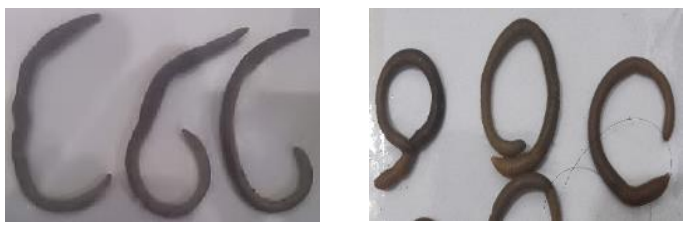

Perlakuanl Alkohol 70\%

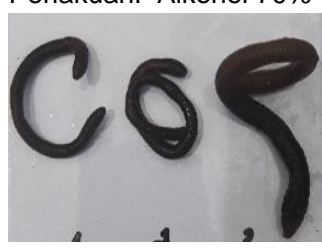

Perlakuan V $(6: 4)$

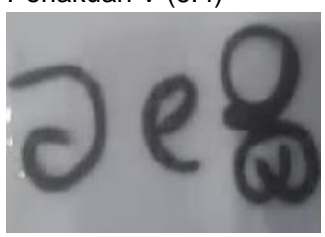

Perlakuan IX (2:8)

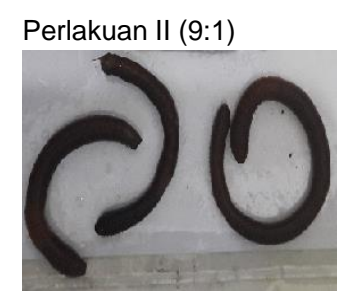

Perlakuan VI (5:5)

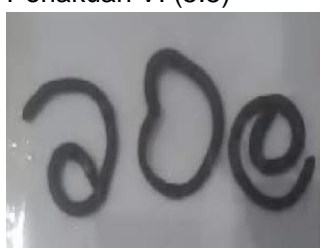

Per;akuan X (1:9)
Secara umum larutan pada pengamatan minggu IV tidak berubah menjadi lebih berwarna coklat dan bertambah keruh dibandingkan dengan pengamatan minggu II sebelumnya. Hanya pada perlakuan VI-1, VII-1, dan VIII-1 larutan tampak menjadi lebih coklat (Gambar 4.). Hal tersebut dikarenakan adanya jaringan dalam yang terlepas melalui luka yang ada. Sifat kimia baik kandungan zat atau keasaman jaringan dalam yang berbeda dapat memberi pengaruh terhadap warna.
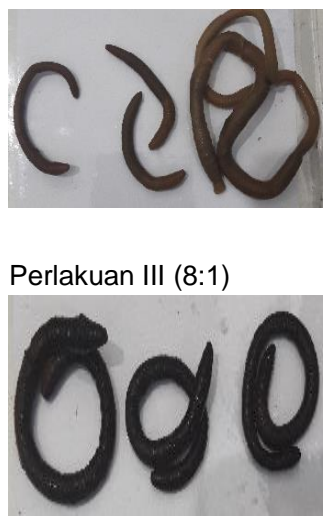

Perlakuan VII (4:6)

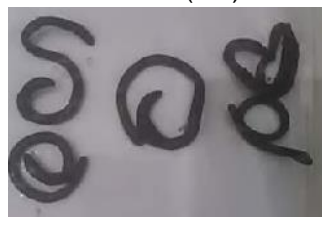

Perlakuan XI Asap cair

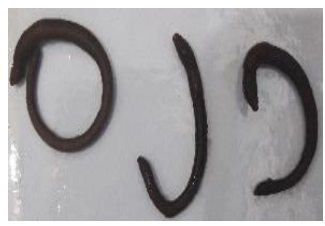

Perlakuan IV (7:3)

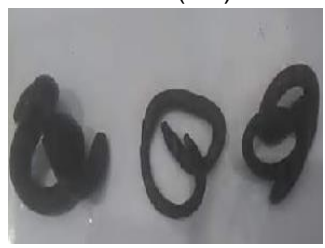

Perlakuan VIII (3:7)

Gambar 3. Kondisi spesimen awetan pada minggu II. Kontras: spesimen perlakuan I tampak pucat sedangkan spesimen perlakuan XI tampak hitam.

Pada minggu ke IV dilakukan penggantian larutan dengan larutan yang baru. Penggantian ini mengikuti prosedur yang dilaksanakan di laboratorium Sistematik Hewan. Penggantian ini dimaksudkan agar sisa-sisa jaringan dapat dipisahkan dari spesimen awetan, dan larutan nampak jernih. Pada pelaksanaan di laboratorium tindakan ini dilakukan juga untuk mensortir spesimen yang gagal diawetkan. Awetan yang baik kemudian akan disimpan sebagai koleksi atau cadangan materi praktikum. 
Tabel 2. Pengamatan Spesimen dan Larutan pada Minggu IV (4 November 2018)

\begin{tabular}{|c|c|c|c|c|c|c|}
\hline \multirow[t]{2}{*}{ No } & \multirow{2}{*}{$\begin{array}{c}\text { Perlakuan } \\
\text { / } \\
\text { Ulangan }\end{array}$} & \multicolumn{3}{|c|}{ Spesimen } & \multicolumn{2}{|c|}{ Larutan } \\
\hline & & Warna & Segmen & Tekstur & Warna & Kejernihan \\
\hline \multirow[t]{3}{*}{1} & $\begin{array}{l}\text { I.1 } \\
\text { Alkohol }\end{array}$ & Memudar & Utuh & Kenyal & Transparan & Jernih \\
\hline & $\begin{array}{l}\text { I.2 } \\
\text { Alkohol }\end{array}$ & Memudar & Utuh & Kenyal & Transparan & Jernih \\
\hline & $\begin{array}{l}\text { I.3 } \\
\text { Alkohol }\end{array}$ & Memudar & Utuh & Kenyal & Transparan & Jernih \\
\hline \multirow[t]{3}{*}{2} & II.1 9:1 & Kemerahan alami & Utuh & Kenyal & Transparan & Jernih \\
\hline & II.2 9:1 & Kemerahan alami & Utuh & Kenyal & Transparan & Jernih \\
\hline & II.3 9:1 & Kemerahan alami & Utuh & Kenyal & Transparan & Jernih \\
\hline \multirow[t]{3}{*}{3} & III.1 8:2 & Kemerahan alami & Utuh & Kenyal & Kekuningan & Jernih \\
\hline & III.2 8:2 & Kemerahan alami & Utuh & Kenyal & Kekuningan & Jernih \\
\hline & III.3 8:2 & Kemerahan alami & $\begin{array}{l}\text { Utuh } \\
\text { Ada luka }\end{array}$ & Kenyal & Kekuningan & $\begin{array}{l}\text { Jernih, sedikit } \\
\text { endapan }\end{array}$ \\
\hline \multirow[t]{3}{*}{4} & IV.1 $7: 3$ & Kemerahan tua & Utuh & Kenyal & Kecoklatan & Jernih \\
\hline & IV.2 7:3 & Kemerahan tua & Utuh & Kenyal & Kecoklatan & Jernih \\
\hline & IV.3 7:3 & Kemerahan tua & Utuh & Kenyal & Kecoklatan & $\begin{array}{l}\text { Jernih, sedikit } \\
\text { endapan }\end{array}$ \\
\hline \multirow[t]{3}{*}{5} & V.1 $6: 4$ & Hitam & Utuh & Kenyal & Kecoklatan & Jernih \\
\hline & V.2 6:4 & Hitam & Utuh & Kenyal & Kecoklatan & Jernih \\
\hline & V.3 $6: 4$ & Kemerahan tua & Utuh & Kenyal & Kecoklatan & $\begin{array}{l}\text { Jernih, banyak } \\
\text { endapan }\end{array}$ \\
\hline \multirow[t]{3}{*}{6} & VI.1 $5: 5$ & Hitam & $\begin{array}{l}\text { Utuh } \\
\text { Ada luka }\end{array}$ & Kenyal & Agak Coklat & $\begin{array}{l}\text { Jernih, banyak } \\
\text { endapan }\end{array}$ \\
\hline & VI.2 5:5 & Hitam & $\begin{array}{l}\text { Utuh } \\
\text { Ada luka }\end{array}$ & Kenyal & Agak Coklat & $\begin{array}{l}\text { Jernih, banyak } \\
\text { endapan }\end{array}$ \\
\hline & VI.3 $5: 5$ & Hitam & Utuh & Kenyal & Kecoklatan & Jernih \\
\hline \multirow[t]{3}{*}{7} & VII.1 4:6 & Hitam & $\begin{array}{l}\text { Utuh } \\
\text { Ada luka }\end{array}$ & Kenyal & Kecoklatan & $\begin{array}{l}\text { Jernih, banyak } \\
\text { endapan }\end{array}$ \\
\hline & VII.2 4:6 & Hitam & Utuh & Kenyal & Kecoklatan & Jernih \\
\hline & VII.3 4:6 & Hitam & Utuh & Kenyal & Kecoklatan & Jernih \\
\hline \multirow[t]{3}{*}{8} & VIII.1 3:7 & Hitam & $\begin{array}{l}\text { Utuh } \\
\text { Ada luka }\end{array}$ & Kenyal & Agak coklat & $\begin{array}{l}\text { Jernih, banyak } \\
\text { endapan }\end{array}$ \\
\hline & VIII.2 3:7 & Hitam & Utuh & Kenyal & Kecoklatan & Jernih \\
\hline & VIII.3 3:7 & Hitam & Utuh & Kenyal & Kecoklatan & $\begin{array}{l}\text { Jernih, sedikit } \\
\text { endapan }\end{array}$ \\
\hline \multirow[t]{3}{*}{9} & IX.1 $2: 8$ & Hitam & Utuh & Kenyal & Agak coklat & Jernih \\
\hline & IX.2 2:8 & Hitam & Utuh & Kenyal & Agak coklat & Jernih \\
\hline & IX.3 2:8 & Hitam & Utuh & Kenyal & Agak coklat & $\begin{array}{l}\text { Jernih, sedikit } \\
\text { endapan }\end{array}$ \\
\hline \multirow[t]{3}{*}{10} & $\begin{array}{ll}X .1 & 1: 9\end{array}$ & Hitam & Utuh & Kenyal & Coklat & Jernih \\
\hline & X.2 $1: 9$ & Hitam & Utuh & Kenyal & Coklat & Jernih \\
\hline & X.3 $1: 9$ & Hitam & Utuh & Kenyal & Coklat & Jernih \\
\hline \multirow[t]{3}{*}{11} & $\mathrm{XI} .1 \mathrm{AC}$ & Hitam arang & Utuh & Kenyal & Coklat & Jernih \\
\hline & $\mathrm{XI} 2 \mathrm{AC}$ & Hitam arang & Utuh & Kenyal & Coklat & Jernih \\
\hline & XI.3 AC & Hitam arang & Utuh & Kenyal & Coklat & Jernih \\
\hline
\end{tabular}




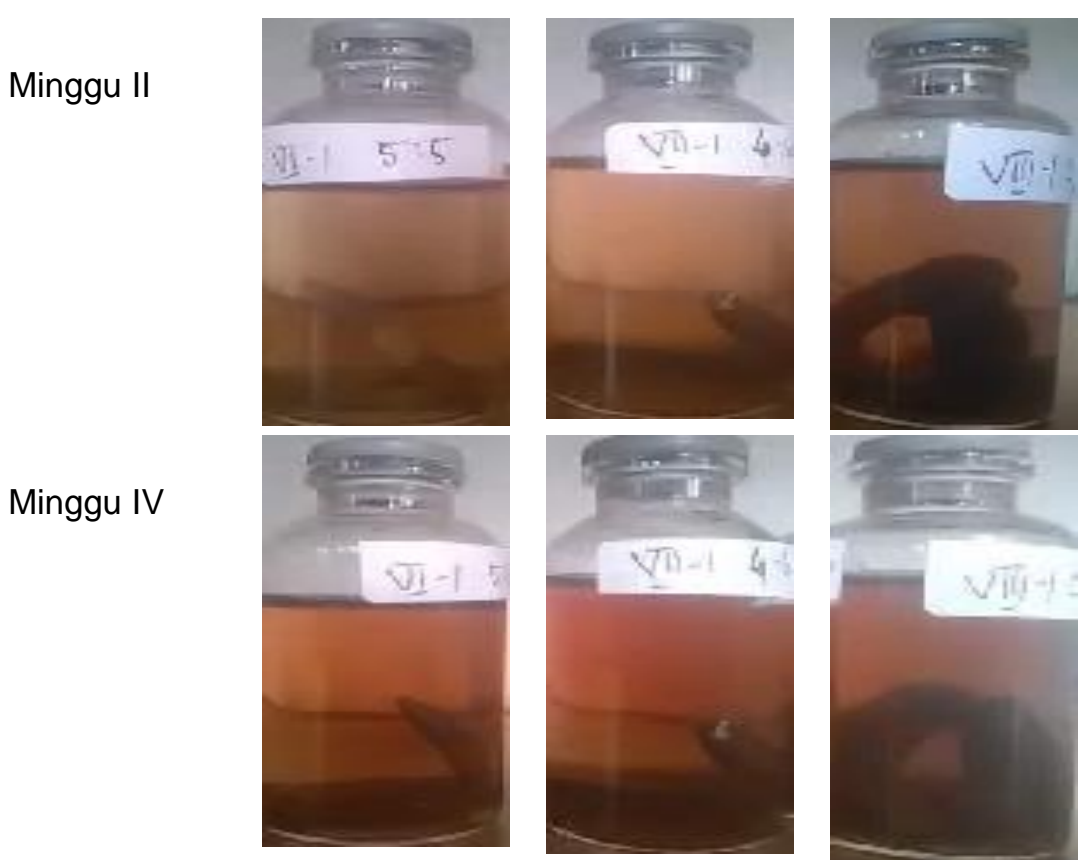

Gambar 4. Perbandingan hasil pengamatan perlakuan VI-1 (5:5), VII-1 (4:6), dan VIII-1 (3:7) pada minggu II dan minggu IV

Pada pengamatan minggu $\mathrm{VI}$ (Tabel 3.) warna tubuh spesimen yang diperlakukan dengan asap cair juga tidak bertambah menghitam yang berarti memperkuat argumentasi bahwa $\mathrm{Hb}$ adalah pigmen yang bertanggung jawab terhadap terikatnya karbon di jaringan spesimen. $\mathrm{Hb}$ darah sudah terfiksasi bersama darah dan berikatan dengan karbon sehingga tidak terjadi lagi penumpukan karbon di tubuh spesimen. Tubuh secara umum baik, segmen utuh, dan kenyal tidak rapuh, kecuali spesimen pada perlakuan I (alkohol $70 \%$ ) dan perlakuan XI (asap cair grade2). Spesimen pada perlakuan I tubuhnya agak menyusut dan melembek, diduga mengalami dehidrasi lanjut. Pada perlakuan $\mathrm{XI}$ tekstur spesimen terdeteksi berkurang kekenyalannya walaupun tubuh secara umum terlihat utuh.

Larutan pada minggu VI tampak tetap jernih dengan warna seperti larutan sebelum perlakuan. Pada perlakuan VI-1 (5:5), VII-1 (4:6), dan VIII-1 (3:7) spesimen dengan luka pada minggu IV menimbukan warna larutan lebih coklat, pada minggu VI tidak merubah warna larutan dan endapan. Keadaan ini dimungkinkan karena spesimen secara umum telah terfiksasi baik. Larutan pengawet telah mengalami penetrasi jauh ke dalam jaringan.

Pada akhir pengamatan (2 Desember 2018/minggu VIII) keadaan spesimen dan larutan tidak lagi menunjukkan perubahan dibandingkan pengamatan minggu VI. Dari pengamatan visual maka spesimen perlakuan II (kombinasi alkohol 70\%:asap cair 9:1) sampai dengan perlakuan IV (7:3) menunjukkan bahwa spesimen dapat diamati bagian luar tubuh: segmentasi tubuhnya jelas, bagian clitellum nampak kemerahan alami-kemerahan tua, dan tekstur kenyal. Hasil tersebut lebih baik daripada perlakuan I (alkohol 70\%), karena pada perlakuan I warna spesimen justru memudar (Gambar 5.). Hal ini sesuai dengan apa yang dijumpai pada penelitian Rahayoe (2016) yaitu bahwa spesimen yang diperlakukan dengan larutan asap cair mampu 
mempertahankan warna alami dari ikan nila, berbeda dengan sifat alkohol yang menyebabkan pudarnya warna. Disamping itu pada perlakuan I tubuh

Tabel 3. Pengamatan Spesimen dan Larutan pada Minggu VI (18 Nopember 2018)

\begin{tabular}{|c|c|c|c|c|c|c|}
\hline \multirow[t]{2}{*}{ No } & \multirow{2}{*}{$\begin{array}{c}\text { Perlakuan/ } \\
\text { Ulangan }\end{array}$} & \multicolumn{3}{|c|}{ Spesimen } & \multicolumn{2}{|c|}{ Larutan } \\
\hline & & Warna & Segmen & Tekstur & Warna & $\begin{array}{l}\text { Kejernih } \\
\text { an }\end{array}$ \\
\hline \multirow[t]{3}{*}{1} & $\begin{array}{l}\text { I.1 } \\
\text { Alkohol }\end{array}$ & Memudar & $\begin{array}{l}\text { Utuh, ada } \\
\text { penyusutan di } \\
\text { beberapa bagian }\end{array}$ & Kurang kenyal & Transparan & Jernih \\
\hline & $\begin{array}{l}\text { I.2 } \\
\text { Alkohol }\end{array}$ & Memudar & $\begin{array}{l}\text { Utuh, ada } \\
\text { penyusutan di } \\
\text { beberapa bagian }\end{array}$ & Kurang kenyal & Transparan & Jernih \\
\hline & $\begin{array}{l}\text { I.3 } \\
\text { Alkohol }\end{array}$ & Memudar & $\begin{array}{l}\text { Utuh, ada } \\
\text { penyusutan di } \\
\text { beberapa bagian }\end{array}$ & Kurang kenyal & Transparan & Jernih \\
\hline \multirow[t]{3}{*}{2} & II.1 9:1 & $\begin{array}{l}\text { Kemerahan } \\
\text { alami }\end{array}$ & Utuh & Kenyal & Transparan & Jernih \\
\hline & II.2 9:1 & $\begin{array}{l}\text { Kemerahan } \\
\text { alami }\end{array}$ & Utuh & Kenyal & Transparan & Jernih \\
\hline & II.3 9:1 & $\begin{array}{l}\text { Kemerahan } \\
\text { alami }\end{array}$ & Utuh & Kenyal & Transparan & Jernih \\
\hline \multirow[t]{3}{*}{3} & III.1 $8: 2$ & $\begin{array}{l}\text { Kemerahan } \\
\text { alami }\end{array}$ & Utuh & Kenyal & Kekuningan & Jernih \\
\hline & III.2 8:2 & $\begin{array}{l}\text { Kemerahan } \\
\text { alami }\end{array}$ & Utuh & Kenyal & Kekuningan & Jernih \\
\hline & III.3 8:2 & $\begin{array}{l}\text { Kemerahan } \\
\text { alami }\end{array}$ & $\begin{array}{l}\text { Utuh } \\
\text { Ada luka }\end{array}$ & Kenyal & Kekuningan & Jernih \\
\hline \multirow[t]{3}{*}{4} & IV.1 $7: 3$ & Kemerahan tua & Utuh & Kenyal & Kekuningan & Jernih \\
\hline & IV.2 7:3 & Kemerahan tua & Utuh & Kenyal & Kekuningan & Jernih \\
\hline & IV.3 7:3 & Kemerahan tua & Utuh & Kenyal & Kekuningan & Jernih \\
\hline \multirow[t]{3}{*}{5} & V.1 $6: 4$ & Hitam & Utuh & Kenyal & Kekuningan & Jernih \\
\hline & V.2 $6: 4$ & Hitam & Utuh & Kenyal & Kekuningan & Jernih \\
\hline & V.3 $6: 4$ & Kemerahan tua & Utuh & Kenyal & Kekuningan & Jernih \\
\hline \multirow[t]{3}{*}{6} & VI.1 $5: 5$ & Hitam & UtuhAda luka & Kenyal & Kekuningan & Jernih \\
\hline & VI.2 5:5 & Hitam & Utuh Ada luka & Kenyal & Kekuningan & Jernih \\
\hline & VI.3 5:5 & Hitam & Utuh & Kenyal & Kekuningan & Jernih \\
\hline \multirow[t]{3}{*}{7} & VII. $14: 6$ & Hitam & Utuh Ada luka & Kenyal & Kecoklatan & Jernih \\
\hline & VII.2 4:6 & Hitam & Utuh & Kenyal & Kecoklatan & Jernih \\
\hline & VII.3 $4: 6$ & Hitam & Utuh & Kenyal & Kecoklatan & Jernih \\
\hline \multirow[t]{3}{*}{8} & VIII.13:7 & Hitam & Utuh Ada luka & Kenyal & Kecoklatan & Jernih \\
\hline & VIII.23:7 & Hitam & Utuh & Kenyal & Kecoklatan & Jernih \\
\hline & VIII.33:7 & Hitam & Utuh & Kenyal & Kecoklatan & Jernih \\
\hline \multirow[t]{3}{*}{9} & IX.12:8 & Hitam & Utuh & Kenyal & Kecoklatan & Jernih \\
\hline & IX.2 2:8 & Hitam & Utuh & Kenyal & Kecoklatan & Jernih \\
\hline & IX.3 2:8 & Hitam & Utuh & Kenyal & Kecoklatan & Jernih \\
\hline \multirow[t]{3}{*}{10} & X.11:9 & Hitam & Utuh & Kenyal & Kecoklatan & Jernih \\
\hline & X.2 1:9 & Hitam & Utuh & Kenyal & Kecoklatan & Jernih \\
\hline & X.3 1:9 & Hitam & Utuh & Kenyal & Kecoklatan & Jernih \\
\hline \multirow[t]{3}{*}{11} & $\mathrm{XI} .1 \mathrm{AC}$ & Hitam arang & Utuh & Kurang kenyal & Kecoklatan & Jernih \\
\hline & $\mathrm{XI} .2 \mathrm{AC}$ & Hitam arang & Utuh & Kurang kenyal & Kecoklatan & Jernih \\
\hline & XI.3 AC & Hitam arang & Utuh & Kurang kenyal & Kecoklatan & Jernih \\
\hline
\end{tabular}

cacing tanah melunak dan di beberapa bagian tubuh spesimen menunjukkan jaringan. penyusutan, akibat terjadinya dehidrasi 

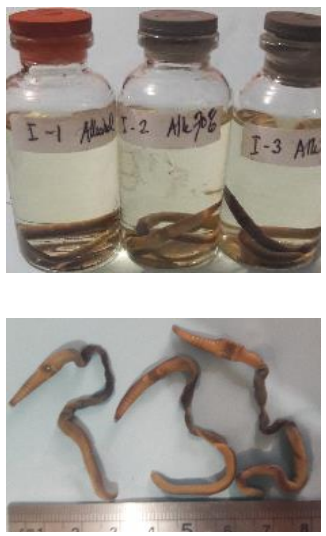

Perlakuan I alkohol $70 \%$
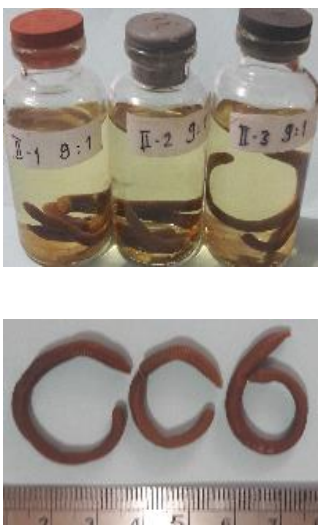

Perlakuan II (9:1)
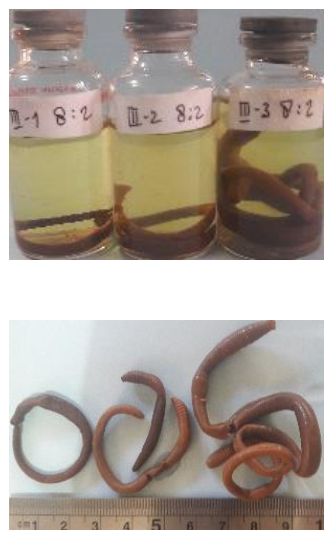

Perlakuan III (8:2)
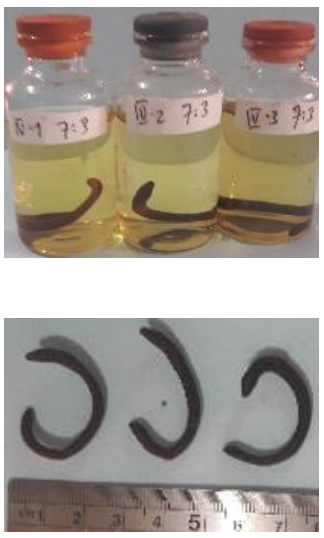

Perlakuan IV (7:3)

Gambar 5. Hasil spesimen cacing tanah (Pheretima sp.) yang baik untuk dapat diamati pada pengamatan minggu VIII. Hasil spesimen dengan pengawet alkohol $70 \%$ warna tampak memudar dan beberapa bagian menyusut.

Pada pengamatan akhir dilakukan uji kekenyalan spesimen menggunakan alat Texture Analyzer. Pada Gambar 6. dapat dilihat kekenyalan spesimen pada kombinasi larutan alkohol dengan asap cair (perlakuan II-IX) memiliki kekenyalan rata-rata lebih tinggi daripada specimen dalam larutan tunggal (perlakuan I/alkohol murni dan perlakuan Xl/asap cair grade-2 murni). Pada perlakuan VII menunjukkan nilai kekenyalan paling tinggi (rata-rata $=53.444 \quad \mathrm{~N})$ jauh melampaui perlakuan yang lain. Terlepas dari perlakuan VII yang menunjukkan perbedaan yang mencolok tersebut, maka hasil pengujian menunjukkan bahwa kombinasi larutan antara alkohol $70 \%$ dan asap cair grade2 memberikan pengaruh terhadap tingkat kekenyalan spesimen. Kombinasi larutan antara alkohol dan asap cair dapat digunakan secara bersama untuk mempertahankan tekstur spesimen. Suntoro (1983) menyatakan bahwa kombinasi larutan pengawet dapat saling melengkapi atau menutupi kekurangan yang ada, sehingga hasil yang diperoleh menjadi lebih baik apabila hanya diperlakukan sebagai pengawet tunggal.

Berdasarkan hasil yang diperoleh maka diperlukan penelitian lanjut dalam penggunaan kombinasi larutan alkohol dan asap cair untuk spesimen anggota invertebrata lain. Tekstur dan ketebalan masing-masing organisme yang berbeda akan berpengaruh terhadap kemampuan penetrasi larutan ke dalam jaringan. Penelitian ini juga belum mengevaluasi daya awet atau daya simpan terhadap spesimen. Daya simpan larutan sangat dibutuhkan untuk ketersedian spesimen dalam kegiatan praktikum, penelitian, dan koleksi laboratorium. Penggunaan kombinasi alkohol dan asap cair diharapkan memberikan hasil awetan yang baik untuk spesimen lain sehingga dapat mengurangi risiko penggunaan alkohol, formalin, dan kombinasi keduanya. 


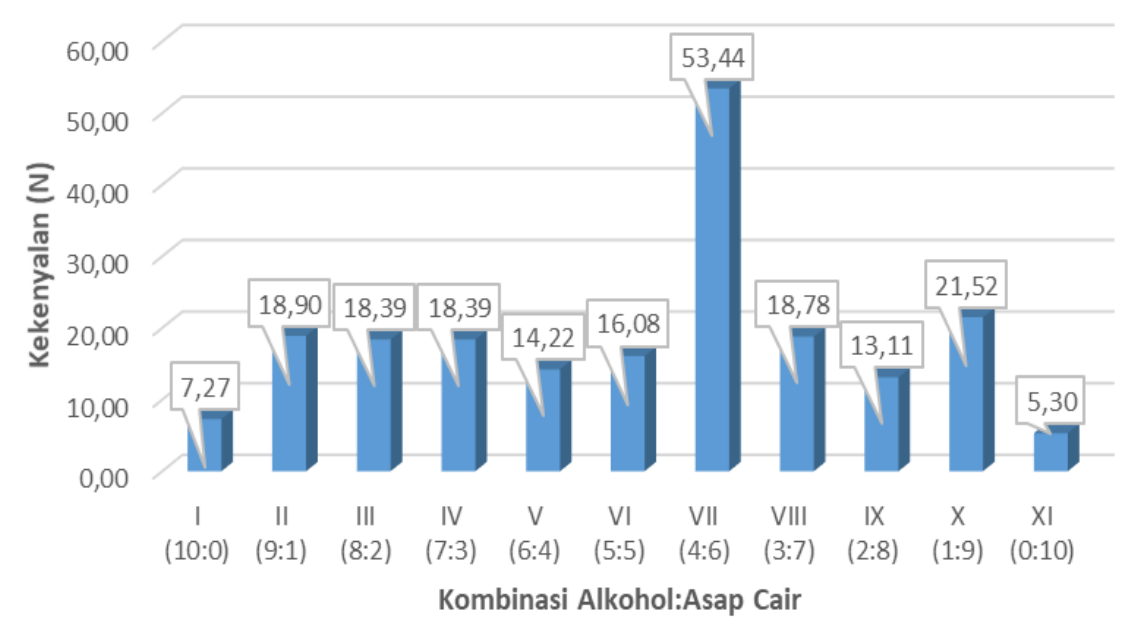

Gambar 6. Grafik kekenyalan rata-rata spesimen cacing tanah (Pheretima sp.)

\section{KESIMPULAN}

Berdasarkan hasil pengamatan dan pembahasan dapat disimpulkan bahwa seluruh perlakuan mampu mengawetkan spesimen, dengan tingkat respon yang berbeda struktur dan kekenyalan tetap terjaga (tidak hancur). Semakin besar kadar asap cair menimbulkan warna yang semakin gelap walaupun secara tekstur permukaan dan segmen tubuh tetap utuh dan kenyal, tidak mengalami pembusukan. Kombinasi perlakuan II (alkohol $70 \%$ :asap cair=9:1) hingga perlakuan IV (kombinasi alkohol:asap cair=6:4) memberikan hasil kenampakan spesimen yang baik (terkesan alami dan jelas untuk diamati). Kombinasi tersebut lebih baik dari pada perlakuan I (alkohol $70 \%$ ). Kombinasi alkohol 70\% dan asap cair grade-2 dapat digunakan sebagai alternatif pengganti pengawetan alkohol $70 \%$.

\section{DAFTAR PUSTAKA}

Brusca, R.C. and Brusca, G. J. 1990. Invertebrates.

Sinaur

Associates. Inc. Sunderland: Massachusetts.

Darmawan, A., Rika Raffiudin, dan Tri Heru Widarto. 2010. Bioekologi Cacing Tanah (Pheretima darnleiensis). http://repository.ipb.ac.id/handl e/123456789/55961

(Unduh:10 September 2018)

Edward, E. Ruppert and Robert D. Barner. 1994. Invertebrate Zoology. Saunders College Publishing. London. Pp. 561568.

Hendry T, S. Saragih, Soesanto Mangkoewidjojo, dan Syarifudin Tato. 2008. Penentuan Lethal Dose 50(LD50) Asap Cair Grade 2 pada Mencit Betina. http://asapcair.blogspot.com/2 008/12/penentuan-lethal-dose50-ld50-asap-cair.html (Unduh: 10 September 2018)

Rahayoe, A.S. 2016. Asap Cair Sebagai Pengawet Spesimen. Prosiding Seminar Nasional Pranata Laboratorium Pendidikan, Universitas Udayana, Hal: 69-75.

Suntoro, S.H. 1983. Metode Perwarna. Laboratorium Histologi \& Histokimia Fakultas Biologi. UGM. Hal 14-17.

Towaha, J. 2013. Pemanfaatan Asap Cair Kayu Karet dan Tempurung Kelapa untuk Penanganan Polusi Udara pada Lump. http://ejurnal.litbang.pertanian. go.id/index.php/bultri/article/vie 
w/2382 (Unduh: 3 September 2018)

Yulstiani, R. 2008. Monograf Asap Cair sebagai Bahan Pengawet Alami pada Produk Daging dan Ikan. Cetakan Pertama. Edisi 1. UPN Veteran Jawa. Timur. 